\title{
THE IDEALISM OF DIALOGUE AND THE ECONOMY OF THE COMMONS ${ }^{1}$
}

\author{
Fernando Suárez Müller \\ University of Humanistic Studies of Utrecht. \\ Christian Felber \\ University of Vienna.
}

\begin{abstract}
This paper explores the possibility of an economic system different from both capitalism and communism, that is based on the major ethical values that constitute the principles of human dialogue, the so-called Idealism of Dialogue. This implies an economic model based on cooperativism. An economy modelled in this way envisions the Common Good of society. This is more than the sum of the interests of individuals and it can be measured by looking at the intended impact on society of actions taken by organizations. If the impact of these organizations is oriented towards cooperative action they can be characterized as developing the Common Good. If they block cooperative action they can be seen to be serving private interests. This paper shows how a group of Austrian entrepreneurs has started a network of enterprises that functions both as a kind of cooperative and as a non-governmental organization (Gemeinwohl-Ökonomie). They promote the ideals of Greek oikonomía and at the same time consider their own efforts to be the accomplishment of the main principles of Enlightenment which are liberty, equality and fraternity.
\end{abstract}

Keywords

Idealism of Dialogue. Cooperativism. Enlightenment. Commons.

\section{O IDEALISMO DO DIÁLOGO E A ECONOMIA DOS COMUNS}

\begin{abstract}
Resumo
Este artigo explora a possibilidade de um sistema econômico diferente tanto do capitalismo quanto do comunismo, baseado nos principais valores éticos que constituem os princípios do diálogo humano, o assim chamado Idealismo do Diálogo. Isto requer um modelo econômico baseado no cooperativismo. Uma economia viabilizada desta forma tem por perspectiva o Bem Comum da sociedade. O que é mais do que a soma dos interesses individuais e pode ser medido pelo olhar voltado para o impacto social das ações tomadas pelas organizações. Se o impacto destas organizações estiver orientado à ação cooperativa elas podem ser caracterizadas como promotoras do Bem Comum. Se elas impedem a ação cooperativa podem ser vistas como agenciadoras de interesses privados. Este artigo mostra como um grupo de empresários austríacos iniciou uma rede de empresas que funcionam tanto como uma espécie de cooperativa quanto como organização não-governamental (Gemeinwohl-Ökonomie). Elas promovem os ideais da oikonomia grega e ao mesmo tempo consideram seus próprios esforços enquanto realização dos mais importantes princípios do Iluminismo, quais sejam liberdade, igualdade e fraternidade.
\end{abstract}

\section{Palavras-chave}

Idealismo do Diálogo. Cooperativismo. Iluminismo. Comuns.

\footnotetext{
${ }^{1}$ This text is a modified and developed version of "Humanisation of the Economy", that appeared in Myrte van de Klundert \& Robert van Boeschoten (2016), Organisations \& Humanisation. Perspectives on Organising Humanisation and Humanising Organisations, Gower. Parts of the text can also be found in Christian Felber (2008), Neue Werte für die Wirtschaft [New Values for the Economy], Deuticke, Vienna, pp. 266-327. Suárez Müller is responsible for translations of passages from the work of Felber.
} 
If we agree to define the humanization of society as the institutional realization of the principles of human dialogue the most essential pillar of society responsible for our subsistence the economy - should not just be perceived as a domain of mere competition. The principles of interpersonal relationship, which constitute the so-called 'idealism of dialogue', include ethical values such as symmetry, equality, liberty, openness, renouncement of violence, tolerance, respect, solidarity, cooperation, responsibility. These values constitute an a priori of righteousness which is taken for granted each time we engage in dialogue. I cannot really engage in an interpersonal relationship without presuming these values to hold; without presupposing that the other person feels a commitment to these same values. To make a free sphere of communication between humans possible, these values must be acknowledged by the interrelating persons. For a 'humanization of the economy' these ethical values must be integrated in all possible layers of the economic system. In an economy that deserves to be called humane these ethical values determine the rules of the game. Humanizing the economy will therefore consist in enabling the economic society to be primarily based on cooperation instead of competition. We shall argue that it is essential for humankind to move towards an economy based on cooperation. If the humanization of the political system refers to a progressively expanding democratization of society - authoritarian structures based on fear thereby being transformed into open systems of political participation - a similar dynamics towards participation will consequently also define the humanization of the economy. A system based on the ideals of humanity (the 'idealism of dialogue') cannot be structured by rules of competition which require winners and losers. Although our modern economic system of free competition (capitalism) is not built on violence and fear as was once slavery and serfdom, competition nonetheless constitutes an organizational model in which the unethical values of violence and fear are very much alive. The humanization of the economy thus ultimately implies the realization of a system of labour based on collaborative principles which envision the Common Good of society - and this is a mirroring of our inner dialogical predispositions. In such a cooperative system of labour, resources will be distributed on an ethical basis. Ethics here becomes an integral part of economics, which is to say that economic thought becomes part of a social enterprise, of a philosophical reflection concerned with the aims of humanity. The sociologist Nico Stehr calls this development the 'moralization of the markets'. This means that economy (both as a science and as a domain of reality) is progressively being reintegrated into 
the domain of practical philosophy. Georg Wilhelm Friedrich Hegel once emphasized that our bourgeois society (capitalism) was based on a model of egoistic subjects that dominated the philosophy of Enlightenment. He emphasized the need to transform this type of society into a system of cooperativeness. Inspired by these thoughts Karl Marx proposed an economic philosophy that went far beyond Hegel's intentions and he conceived a type of labour society that would eradicate all private property. We are now discovering the possibility of an economic system that transcends both capitalism and communism. A theory of humanization could clarify the philosophical framework for such a system.

\section{HUMANISM AND CAPITALISM}

The current, neoliberal, stage of capitalism is characterized by the fact that more and more vital parts of society are being dominated by economic imperatives. The values represented by these economic imperatives are claimed to have a proper legitimation based on the natural rules of the market. But the ethics of the economic domain should not be different from the general ethics of society. The economy is seen primarily as a natural entity, with natural laws and rules, and not as a creation of the human spirit. This natural sphere of the market is dominated by blind efficiency and the unlimited pursuit of profit, and is in fact very different from the sphere of humanistic values in which we expect solidarity, mutual help and sharing. These two spheres do not match but ethics cannot be split up. This false separation that allows the economy to be ruled by different values from those characterizing human relationships is the product of the modern science of economics which takes the market to be something abstract, autonomous, separated from other domains of society. The science of economics imagines this abstract domain to have its own ethical rules which are deemed to be different from those held by society. It is the cultural achievement of modern capitalism to integrate this abstraction within a frame of legitimacy and legality. Capitalism is now represented by the law. It has become completely natural to subdue people to market imperatives, to violate the dignity of humankind in the name of this one-sided rationality, and to destroy our environmental and social ties in the name of efficiency and profit. It is seen to be successful to increase capital by cutting jobs, and to let others work for us is taken to be a personal accomplishment. This doubled and ghostly ethics must be put back in the bottle. These non-values should be laid upon the compost heap of ethical history. 
Since the economy is part of society its values must be those of society. The values that constitute the centre of society, that make relationships between parents, children, friends, and neighbours prosper - these values should be carried inside the economic domain and they should determine our economic way of life. What has proved itself in society is also beneficial for the economy. The economy is an integral part of social life and is itself part of our interpersonal relationships. The economy consists of extremely tied relationships and we must take care that the values involved in this domain are the right ones. The idea that human values function only in the small and private domain of familiar and close relationships is a clear underestimation of humankind. Why should we not be able to treat people who are far away from us fairly? Fair trade is a firm rebuttal of the claim that people become evil predators once their relationships become global. It is a rational decision of free people that takes place without any legal pressure. The anonymity of the market can seduce some of us to pursue our own gain at the expense of others, but this seems also to be possible locally, in small enterprises. The distances of the global world are not to blame for this attitude, instead it is the belief in the imperatives of market efficiency and the transformation of the interpersonal relations of mutual trust into legal and legalized contracts of exploitation that are to blame. Patriarchal attitudes in household relationships are similar to these kinds of economic global structures. If ethics on a global scale were pointless we should stop any attempt to create a global domestic politics, we should close the United Nations and revoke the Universal Declaration of Human Rights. But of course the contrary must be done: we need to globalize what proves to work on a local level!

\section{OİKONOMÍA. AN ALTERNATIVE FOR COMMUNISM AND CAPITALISM}

The Greek called the science of the household "oikonomía". Sharing and responsibility were the dominant values of the household and in fact this has not changed. Of course there is no need to romanticize the Greek system since we all know that it was based on slavery, women were not equals and patriarchal attitudes would probably have been very common. Nonetheless the theory of oikonomía, as it was developed by Aristotle, takes the economy not to be based on the idea of egoistic individuals competing for profit but on the idea of small communities dedicated to the common good and based on interpersonal values and imperatives of responsibility. In this science of oikonomía economic imperatives did not have an existence of 
their own, they were always considered within the scope of ethical rules. The economy of a nation (the polis) was perceived as an interrelation, a network of households (oikoi). The idea of a well-ordered state, a politeía as Plato had already called it, was a major preoccupation of Greek philosophy. In it no part of society escapes the ethical rules. The economic discourse of ancient philosophy was what is now rediscovered as a 'moralization of the markets'. It is only in modernity that domains of human culture are treated as if they were natural entities with their own dynamics. But the laws determining the economy are only fallaciously independent from the cultural and political settings in which they are immersed. On a deeper level we have come to understand that there is no escape from a 'Greek approach' that connects all social domains to ethical values.

\section{ECONOMY FOR THE COMMON GOOD}

In order to promote an economic system based on interpersonal ethical values, a nonprofit organization (Economy for the Common Good) was founded in 2011 in Austria. Pioneering enterprises joined forces to create an economic model dedicated to the promotion of ethical 'profits'. This network of pioneers has been able to progressively develop a system of ethical accountancy that can be used in order to determine the amount of ethical progress made by both for-profit and not-for-profit organizations. The idea of an economy based on the 'Common Good' has now spread to most countries in Europe and South-America. Each day thousands of entrepreneurs try to implement the ethical rules (summarized in a balance sheet) which in a process of co-evolution they have created themselves. They are the pioneers of what we call the humanization of our economy. The network integrates new insights and experiences into a document for general use. Of course these practices are practices of corporate social responsibility (CSR) which have separately been developed in several other places during the last decades. They are a symptom of the 'moralization of the markets' referred to above. But in a sense Economy for the Common Good is different because it also develops a vision about how the whole of society should be structured. The CSR-activities developed by this organization are not just heading towards an improvement of the ethical dimension of their own enterprises. The idea is to create a network of ethical entrepreneurship that will change the whole of society, and consequently the whole of the economy, in a well determined direction. Economy for the 
Common Good therefore not only sets out to elaborate a CSR-document that is freely available for all companies which want to adhere to the network, it also sets out to begin transforming the overall structure of the global economy. Therefore it is also a platform for ideas about how to change the political system, how to elaborate and implement new forms of democracy, and, even more important, about how to help change each other's infrastructural mentality and attitudes which have been seriously affected by the long cultural period of modern capitalistic expansionism. Its activities are therefore not only concerned with corporations, but with all kinds of social organizations (they are strictly speaking not just a CSR-strategy but also an OSRstrategy, a strategy for social responsibility in all kinds of Organizations). Many of these ideas have been taken up in the book that gave this organization its name.

One of these ideas is the creation of an economic convent ('con-venire', coming together) in order to define (for a determinate time) what the common good is. Different stakeholders would participate in the formulation of this document which would then be voted on by all citizens. This document should establish the ethical limits for all enterprises. It would define the indicators of 'social and ecological success' that should be directly measurable in companies and other organizations. The rationale of such a convent is the idea that the ultimate value of corporations is not to make profit by way of competition. The ultimate goal is not profit in itself, but the development of an ethical and social attitude using as much money as possible to strengthen the common good and consequently cooperation. In our current situation there are different non-binding CSR- and ISO-standards to measure the non-profit goals of enterprises and products. The economic convent would optimize this situation by creating a binding standard approved democratically by all citizens, general enough to be applied in all different sectors and organizations.

Another idea concerns the support that organizations may expect from making ethical progress. This support should not just be left up to consumer citizenship, instead a whole organizational network should be involved in a web of assistance. Organizations committed to the common good should support each other and support those companies that take their ethical standards seriously. Municipalities and local authorities can support enterprises committed to the common good by giving them priority in open tenders, or by reducing their taxes. Governments can approve laws to encourage ethical attitudes of organizations. 
It is very important to consider what to do with the financial profits of enterprises. These should be seen as means and not ends. Profits should be reinvested in society. Profits can be used for investment in labour and innovation but only if certain social and ethical standards are met. Profits should not go to people who do not work in the company unless there are social or ethical reasons. This of course has repercussions for shareholding in general, since capital shares directly benefit the individual pockets and not the common good. Neither should profits be used to support political parties. The general idea is that in organizations there should always be an ethical discussion about where the profits flow to.

The establishment of a democratic bank is also an idea developed by Economy for the Common Good. This would not be a profit-oriented bank and would strictly limit its investments to supporting enterprises adhering to the common good network. Credit would be based on savings and there are no accountancy tricks to create new money. There are neither lending nor savings rates, just a fee to cover costs and inflation. The democratic bank shows savers what happens to their money and makes it possible for them to determine where it goes. When banks and enterprises are freed from dealing with interest they will also be freed from compulsory growth.

Private property need not be abolished, but it should be acknowledged that too much property in the hands of a minority is a real danger for democracy - as it is for the planet. As Thomas Piketty has shown, the increasing inequality in our societies is contrary to the basic principles of a democratic social state in which there should exist equal rights and equal access to participation. That the unlimited accumulation of property endangers the planet hardly needs saying. An abolition of private property, as proposed by communism, does not acknowledge the merits of individuals but actually we need the principle of negative feedback to control the inequality of material and financial possessions. The 'positive tendency' to inequality must be reversed by a 'negative tendency' that restores equilibrium. These types of negative feedback are simultaneously necessary at different levels of society-the idea is to control economic expansionism. At the micro-level, inequality among individuals can be influenced (creating a negative feedback) with laws limiting wage development and property. At the meso-level inequality among organizations can be influenced (creating a negative feedback) by controlling the size and property of enterprises. At the macro-level our whole society should develop a negative feedback by setting limits to economic growth. The idea of setting negative feedback 
limits to property was proposed by Plato (although of course he did not use the language of systems theory) and was rediscovered later within British Idealism, and then it served as a model for William Beveridge's concept of the modern social state (functioning by means of taxes) in which it mainly functioned to improve social infrastructures and financial redistributions. ${ }^{2}$ It would now also be used to protect the planet by creating ceilings to human expansion. In a certain way it means that a sustainable society of the common good puts an end to what once was ideologically called an 'open society' but in fact just served to promote human expansionism. So, the idea is not to abolish property itself, but to abolish 'expansionist property'. In general, Economy for the Common Good would like to promote the constitution of modern cooperatives or commons (German: Allmenden). Essential infrastructures of our economy should remain under the control of citizens and should neither belong to private companies nor to the state. This has nothing to do with communism or Marxism, the discussion on the commons goes back to the times of Plato and Aristotle. ${ }^{3}$

\section{THE BASIC ETHICAL VALUES OF MODERNITY AND THE NEW ECONOMIC RULES}

In order to be able to talk about the humanization of society the interpersonal values that constitute the 'idealism of dialogue' must find an institutional or organizational translation. Basic ethical values correspond to well-defined practices. We can show this by reflecting on the meaning of the central values of modernity developed during the French Revolution ('liberté, égalité, fraternité'). These values call, as we hope to show, for specific practices that should be accomplished by all types of organizations.

\section{Liberty}

One of the main values determining our modern concept of humanity is certainly liberty. This term is fundamental for all progressive movements, and also for less progressive ones. Even

\footnotetext{
${ }^{2}$ William Beveridge (1942), Social Insurance and Allied Services. See: http://www.sochealth.co.uk/resources/public-health-andwellbeing/beveridge-report/

${ }^{3}$ Joachim Radkau (2008), Nature and Power. A Global History of the Environment, Cambridge Univ. Press, Cambridge/New York; Ostrom, Elinor (1990), Governing The Commons. The Evolution of Institutions for Collective Action, Cambridge Univ. Press, Cambridge/New York.
} 
the most tyrannical regimes of the past century, Stalinism and Nazism, claim a legitimation based on the term. These claims however cannot be taken seriously once we understand liberty in the sense it has in the context of the 'idealism of dialogue'. People who talk to each other do not at the same time use physical violence against each other. We could claim that scuffles and battles are interpersonal relationships but they are certainly not part of our dialogical nature. A dialogue can end up in an argument but when this happens we are in fact pulled away from our most humane values, which is probably the reason we have feelings of discomfort after quarrels. Liberty is certainly the highest legitimation value of modern expansionist capitalism. In a certain sense it is the most harmless value of the French Revolution for the modern growth paradigm. ${ }^{4}$ This ideal gives liberalism and neoliberalism their name. And in a very broad sense the main values of liberalism are integrated into the idea of an economy for the common good. Today, only a fanatic minority would refuse to accept political liberalism understood as democratic tolerance of other opinions. Also, entrepreneurship is a central virtue in an economy for the common good but we are then speaking of 'full' entrepreneurship which necessarily includes an eco-social commitment and considers this to be the real end of all personal labour. In this case we are talking about engaged entrepreneurship not about unlimited private accumulation. As an idea committed to entrepreneurship the Economy for the Common Good naturally acclaims individual merits, but without falling back into one-sided meritomania. In the name of freedom an economy for the common good cannot empathize with economic liberalism. Neoliberalism radicalizes economic liberalism and wants us to believe that liberty just offers one choice (and in fact no choice at all - there is no alternative, as Margaret Thatcher once said), which is the maximization of free trade. To Friedrich von Hayek and Milton Friedman the only resting option is slavery. ${ }^{5}$ To them expansive capitalism is a necessary condition of political freedom. According to them the fundamental rights of humankind are private property and competition which, being basic, should preferably not be limited in any circumstance. In this sense neoliberalism is in fact a hypertrophy of the atomistic model of society defended by empiricist and sceptical philosophers of the Enlightenment. But fortunately there is another Enlightenment which was much more idealistic and which strongly reacted against this reductive interpretation of humanity (Jean-Jacques

\footnotetext{
${ }^{4}$ Koo van der Wal (ed.)(2004), Vrijheid, Gelijkheid en Broederschap? [Liberty, Equality and Fraternity?], Damon, Budel, p. 18.

${ }^{5}$ Friedrich von Hayek (2007), The Road to Serfdom, Univ. Chicago Press ( $\left.{ }^{1} 1944\right)$; Milton Friedman (2002), Capitalism and Freedom, Univ. Chicago Press ( $\left.{ }^{1} 1962\right)$.
} 
Rousseau, Johann Gottfried Herder, Immanuel Kant). The line of philosophy inspired by them offers a basis for the rediscovery of the idea of the common good.

According to Economy for the Common Good the motto of the French Revolution 'liberté, égalité, fraternité' should be read following the order of the words: freedom comes first but only as long as it makes equality and fraternity possible. Cooperation rather than competition should define the content of liberty. Real liberty is about the necessity of limiting itself when meeting others. ${ }^{6}$ Liberty should not be understood as a form of unlimited expansionism, but as the desire to encounter a boundary outside us that induces us to cooperate. Free development cannot be understood in a merely expansive way; it is first of all a process of Bildung, of formation and constitution of the Self. This has nothing to do with continuous growth. Freedom brings us to cooperation, which is a strategy of survival. Humanity's survival has been determined by its capacity to cooperate. To relate liberty with continuous growth is probably connected with the modern idea that there is nothing beyond life; the ultimate goal of life seems to be just to survive and to do this as comfortably as possible. The natural tendency of humans to seek self-affirmation through communication with others ends up in the need to get recognized by others through the admiration resulting from an unlimited accumulation of money ${ }^{7}-$ money being the expression of the possibility to have and to do what we want. Happiness is then wrongly measured as the expansion of the will, whereas the will is in fact, as we see it, seeking to set down moral boundaries within which it can develop itself in cooperation with others.

What follows from these reflections on liberty is that an economy that stands for liberty must assure survival and education for all. A basic income needs to be guaranteed as well as the potential to deploy and develop one's talents and interests in a system committed to Bildung. This is not just education in the sense of a mere internalization of information: it is a reflection on the moral boundaries of all types of action and knowledge. To guarantee a supportive income for all and to realize the idea of Bildung as a basis for moral reflection that helps to develop a broad sense of responsibility are both fundamental issues related to the idea of personal freedom and political liberty as conceived in the context of an economy for the common good. Labour organizations, in which people spend most time of their life in order to make a living, should also attend this need of Bildung.

\footnotetext{
${ }^{6}$ Felber, Christian (2009), Kooperation statt Konkurrenz [Cooperation instead of Competition], Deuticke, Vienna.

${ }^{7}$ It was Adam Smith who related capitalism with the desire of man to get recognition from others. See "Of the Nature of Selfdeceit” in: Smith, Adam (2009), The Theory of Moral Sentiments, penguin, London/New York, pp. 180-186 ( $\left.{ }^{1} 1790\right)$.
} 


\section{Equality}

If liberty is not the unlimited expansion of the will, it is the ability of the will to set itself boundaries. That's why the will turns towards an encounter with the equal. This seems to culminate in a sentiment of affection for the other that we call love. The equal is not identical, since it is different, but it is symmetrical and, in a sense, part of a higher unity comprising the equals. In various senses equality is the end of liberty since liberty moves towards the equal but the equal limits personal freedom. Humankind is the only species capable of reflecting on these processes and any human will automatically recognise other beings capable of this reflection to be its equals. But this does not automatically imply a recognition of equality. An enemy is recognised as an equal that endangers my dignity and that is therefore rejected, which means that the initial recognition is finally refused. A pure system of economic competition is based on the idea of existential selection - the existence of the other must be annihilated. This cannot be compared with a mere sporting event since the basis of the economy, labour, is the individual effort to secure survival. To create or maintain a system of competition is to create or maintain a system in which there are losers and winners, in which some lose their jobs in order to secure gains for others. ${ }^{8}$ This creates and maintains a system of distrust that generates oppositions. In a society of isolated individuals the state becomes a formal and external disciplinary machine that has to secure individual rights without being an object of identification.

That's why Economy for the Common Good strives to promote forms of community life. People can get mobilized around initiatives working with memberships in which, on different levels of society, processes of democratization can create a system of cascading democracy that unites representative, direct and participative forms of democracy. Engagement is what makes these memberships possible. Society is not conceived as a sum of individuals united by an abstract state, but as a circle of circles, as it is called in the Platonic tradition, each circle being a community that can include many communities or be in touch with other communities on different levels. Real political liberalism requires broad political participation. Economy for the

\footnotetext{
${ }^{8}$ Ulrich Beck reserves the term "Angstgesellschaft" ("society of anxiety") to our current risk society, but the term can be employed to characterize modern competitive capitalism in general. See Ulrich Beck (2007), Weltrisikogesellschaft [World Risk Society], Suhrkamp, Frankfurt am Main, p. 28.
} 
Common Good proposes the combination of political and economic participation: democratic processes should not only be broadened in society, they should also be installed in the meso-level of organizations and companies. To Economy for the Common Good the exemplary model that serves as a guideline for all types of labour organizations is the cooperative. This model is neither collectivistic nor individualistic, but a synthesis of both.

\section{Fraternity}

Equality can only be achieved to the extent that people have equal opportunities. Potentiating equality of opportunities also gets us to ideas of self-responsibility and autonomy. Equality of opportunities should not be reduced to an equal access to education, since that equality is primarily monetary. That's why there should be a ceiling on income and property, while at the same time taking care not to destroy the basis of individual merits. Equality should never be reduced to uniformity, as this would imply a collectivist model in which individual differences were ignored. Liberty, equality and fraternity are in fact values defining the higher value of justice. Ignoring individual differences would annihilate the idea of a correlation of liberty, equality and fraternity, and make the whole enterprise of humanization senseless. Only when people have similar opportunities can society become something more than a compound of single unities. There can only be real cooperation if people are equals and consider each other to be equals. Liberty and equality are therefore a precondition for fraternity. Real fraternity comes from the inside. Autonomy is the acknowledgement of the moral law that resides in us and speaks to us. This moral law speaks of justice, of doing justice to all entities on earth (not just to humans). Justice is in fact about the dignity of things. But it is a cooperative enterprise to understand this voice coming from inside oneself. This cooperative effort was once called church.

The idea of the common good can therefore not just be identified with a project of universal solidarity. This is only an aspect of what fraternity really means. In a sense 'solidarity' is just a correctional social measure to overcome the isolation of citizens. When solidarity comes from the inside we are approaching fraternity but this type of solidarity is not just an emotion: it is the openness of the mind to the inner call demanding us to labour for a community of the soul with all living creatures. The economic system is not something separated from this moral domain; it is in fact its major road of completeness in a way that is very different from the 
individual promises of puritan Calvinism which laid the basis of modern liberalism. ${ }^{9}$ The idea of an economy for the common good continues the project of modernity by rationalising the inner connection of 'liberty, equality, fraternity' to an ultimate end, but at the same time it transcends modernity by identifying secularism as a representation of early modern atomistic isolationism. All efforts therefore must be focused on the realization of a cooperative system of labour. To the Greeks, the market (agora) was not just a place of commerce, it was also the instantiation of the 'idealism of dialogue'.

\section{BIBLIOGRAPHY}

SUÁREZ MÜLLER, Fernando. The Process of Humanization. In: KLUNDERT, M. van de; VAN BOESCHOTEN, R. (Ed.). Organisations \& Humanisation: Perspectives on organising humanisation and humanising organisations. Nova Iorque: Gower Publishing, 2016. Cap. 1.

STEHR, Nico. Die moralisierung der märkte: eine gesellschaftstheorie. Frankfurt: Suhrkamp, 2007.

Aristotle. Oeconomica. Loeb: London, 2010.

WELZER, Harald. Selbst Denken: eine anleitung zum widerstand. Frankfurt: Fischer, 2013.

GEMEINWOHL-ÖKONOMIE. Handbuch zur Gemeinwohl-Bilanz. 2013. Disponível em: <https://www.ecogood.org/sites/default/files/dateien/page/handbuch_v4.1_offical_release.pdf>. Acesso em: 30 mar. 2016.

CRANE, Andrew et al (Ed.). The Oxford Handbook of corporate social responsibility. Oxford: Oxford Handbooks, 2009.

FELBER, Christian. Die Gemeinwohl-Ökonomie: das wirtschaftsmodell der zukunft. Viena: Deuticke, 2010.

\footnotetext{
${ }^{9}$ Max Weber (2012), Die protestantische Ethik und der Geist des Kapitalismus [The Protestant Ethic and The Spirit of Capitalism] in: Religion und Gesellschaft, Wbg, Darmstadt, pp. 80-147.
} 
PIKETTY, Thomas. Le capital au XXI' ${ }^{\mathbf{e}}$ siècle. Seuil: Paris, 2013.

Herman Daly, For the Common Good, Beacon, Boston $\left({ }^{1} 1989\right)$, and H. Daly (1991), Steady-State Economics, Island Press, Washington ( $\left.{ }^{1} 1979\right)$; Niko Paech (2011), Befreiung vom Überfluss. Auf dem Weg in die Postwachstumsökonomie [Liberation from Abundance. The Road to The Postgrowth Economy], Oekom, München. 